Integritas 2.3 (Fall 2013), pp. 15-18.

doi: $10.6017 /$ integritas.v2i3p15

\title{
Response to David Quigley
}

\author{
John D. Cunningham, S.J.
}

I want to thank David for an insightful exposition of the history of the Liberal Arts core in Catholic Higher Education. There is much here about which I will ponder for some time.

As David states in his thesis, he explores "the ways in which attention to historical developments, shifts, and even reversals can alert us to the ongoing and dynamic tensions between foundations and innovation in Catholic higher education in the United States." To use history to expose the conflicts and the realities of the "core" today offered me some consolation about a very complicated and emotion-laden topic at most institutions. My consolation is that it is an important component to the dynamic reality of intellectual thought and practice that continues to reflect our contemporary situation.

David begins his paper by examining the unique position of Catholic higher education in this country. We are indeed fully American reflecting the historical realities of our country. It was fascinating for me to realize that the early, Protestant-affiliated colleges in the U.S. began with the goal of educating men for ministry. That is also the deepest root of many of our Catholic institutions. I reflected how it has only been decades now that women have been welcome at most of our Catholic institutions. It is instructive to realize, as David points out, that the founding religious orders of many of our institutions had strong roots from Europe. For much of this country's history, Catholics have often been labeled "suspect" given their European and "pontifical" roots. As an aside, might we ask ourselves if the Catholic colleges and universities in this country have been all too quick to conform to our "native" counterparts in higher education to be accepted

Rev. John D. Cunningham, S. J., is an Associate Professor of Physics at Loyola University Chicago. His research interests are in the field of Experimental Particles and Astrophysics: Cosmic Rays, Dark Energy, and Heavy Quark Particles. He has done research at the Fermi National Accelerator Laboratory and the Argonne National Laboratory. His current physics research involves the simulation and study of various types of supernovae for an upcoming experiment. He is also working on a research project for Loyola's Center for the Catholic Intellectual Heritage on Joseph Bonnecamps, S.J., a French Jesuit mathematician, scientist, and hydrographer who taught at the Jesuit College in Quebec in the eighteenth century. 
as "truly American?" Are the parameters of U.S. Catholic higher education that much different than our secular counterparts?

David also identifies that our U.S. Catholic institutions are unique in reflecting the legacy and practice of the various founding religious orders in regard to education. The legacy of Jesuit colleges is one that reaches back some five centuries. In recent years, much re-examination of that history has revealed the roots of the Liberal Arts Core in such documents as the Ratio Studiorum, a document that David points out shaped "centuries of Ignatian education around the globe with its clear articulation of the centrality of the liberal arts."

David chose a period between two wars, the U.S. Civil War and World War II, to explore the most dramatic changes that occurred in both U.S. and Catholic higher education. I had to chuckle a bit here pondering if the images of war in regard to a discussion of the core might have some underlying meaning?

This near-century of history resulted in incredible changes in American colleges and universities. As David points out in his paper, one was "the rise of the modern research university re-oriented toward graduate and professional education." But why and how did this happen? David passes over these questions, but I think the answers have much to say about why the core continues to change.

I would argue that from the U.S. Civil War (mid-Igth century) until World War II (mid-2oth century), there was a revolution in the academic and intellectual world with the creation and rapid development of many new fields of study. These include behavioral psychology, quantum and particle physics, political and economic philosophies and systems, genetics, and the historical-critical method in theology, to name a few. Who would believe that by the end of this period some Catholic theologians would become respected Scripture scholars?

The progress and changes in these fields were indeed "explosive" as measured in rapid change decade by decade. Who could imagine that the discovery of the electron in I898 would result in the emergence of nuclear theory just two decades later? And sadly, who could imagine the geopolitical ramifications of using this theory to create weapons of unimaginable destruction shortly thereafter?

The rapid expansion of science during this period in parallel with the Industrial Revolution formed the birthplace of modern technology. As David asks early in his paper, "Where is technology leading us?" Given our modern reality this is indeed an important question to be considered.

All of these new fields of study were changing so fast that many sharp, young minds raced to graduate school to become a part of this academic tsunami. And as knowledge of these fields expanded so rapidly, the expertise and background to comprehend them grew exponentially as well. Something in the core had to go. The bachelor's degree was no longer a source of base knowledge and a broad education. It was now a tool needed to succeed in further graduate studies.

I would argue as well that the explosion of knowledge between the mid-nineteenth 
and mid-twentieth centuries also profoundly affected the structures of American universities. The emergence of isolated departments full of specialized individuals, governed by separate colleges, resulted from these changes. This situation continues to influence many of the debates about the core at most of our institutions. In my limited exposure to such discussions, most of the anger expressed seems to center on "turf wars" between departments. David mentions this in his paper. In regard to the core at Georgetown, he writes, "The growing complexity of the university, internal divisions among faculty, and a broad questioning of the idea of the core curricula, among other factors, helped to explain the demise" of attempting to modify the core.

As I read through David's paper, two broad categories kept emerging for me in regard to the core. And I am going to borrow a theological idea in labeling them. I see the attitude toward the core as having two poles: the "core from below" and the "core from above."

The core from below is the core that results from students who want something different from the core. David mentions two situations identifying this notion. In an upcoming history of Boston College, the author argues that Boston College graduates of the late Igth century were being denied admission to Harvard's graduate school, but not because of their Catholic and Irish background. They were being denied admission due to their inferior academic preparation. David also mentions troubled post-war Georgetown administrators (here I imagined a group of crusty, old Jesuits!) bemoaning the drop-off of enrollments in Latin and Greek at the university. (I don't blame those Georgetown students for dumping three years of Latin and Greek!)

The core from above is the core that results from a group of college administrators, usually chairs and deans, as well as selected faculty, who decide the characteristics of the core based on what they think is best. This is frequently how change occurs in the core. I ask, How many students are invited to these meetings and what voice are they given?

David makes it clear that an unbridled core from below can be problematic. He mentions his own educational background of one required core course in his undergraduate degree! Here too I agree. Education involves the growth and transformation of a person at many levels. Wisdom and experience are essential in plotting the path of courses, majors, and certainly academic degrees.

But I would argue too that the voices and experiences of our students cannot be dismissed either. From my perspective as Jesuit priest, professor, and now administrator, I am compelled to embrace the core from below. As chair of the Physics Department at Loyola Chicago, I was surprised to discover the department's strong bias against accepting advanced placement credit in Physics for freshmen interested in pursuing the subject. More and more of our freshmen are being denied advanced placement credit at Loyola. Is the core from above to blame?

There are certainly many dynamics out there exerting great pressures on our students. Due to ever-decreasing research funding, graduate schools are becoming much more selective. At Loyola Chicago, some of our Physics majors have been told 
by some research institutions that their undergraduate Physics education is inferior because they lack courses such as Quantum Mechanics II on their transcripts. Given our core at Loyola, there really is no room for that course in the I20-credit limit of our bachelor's degree.

Many students arrive at our institutions not with advanced placement credit, but rather, some serious deficiencies in their writing and mathematics skills. Early in this semester I had a conversation with an Hispanic freshman, a promising graduate of the Chicago Public Schools system, who had come to the realization that his whole freshman year of supplemental courses in mathematics would put him one year behind his peers in studying Physics. As he pointed out to me, he would not be able to achieve a bachelor's degree in Physics in four years. And he could not afford a fifth year; his scholarship stops after four. What now for this young man?

David concludes his paper with three thoughts in regard to the core from his perspective as Dean and historian. One of them he repeats throughout the paper: "The variousness of cores across our campuses is a strength of Catholic higher education, even as the range of programs and structures demand that we question just what it is that we mean when we talk about the core." I would argue that the core at our many varied Catholic colleges and universities reflects the diverse groups of students who attend each of these institutions. Given their backgrounds, needs, and expectations, each institution has had to adopt a core from below while reflecting on the wisdom of the core from above. This will indeed continue in the decades ahead.

But does the trajectory of David's history imply that the core will continue to be whittled and whittled away? Do we not need to address this trajectory in Catholic colleges and universities with concrete guidelines and even some "brakes"?

That explosion of knowledge during the mid-nineteenth to mid-twentieth centuries had the subtext that humanity was now able to solve many of its problems. Our increased knowledge of science has helped us live longer, healthier, and easier lives. Our understanding of psychology gave us the tools to understand our deepest motivations. Our exposition of sacred texts offered us a deeper appreciation of our religious faith. But is it not true as well that given the horrors of World War II, many of which were begun in the very places where these wonderful new fields of study first began, and the contemporary realities of violence and poverty both here in the U.S. and around the globe, humanity really has not changed that much since the mid-nineteenth century? There is a part of our lives as human beings that we really do not understand. This is why a core at our Catholic colleges and universities is so important. 